\title{
Beyond General Political Attitudes: Conspiracy Mentality as a Global Belief System Predicts Endorsement of International and Local Conspiracy Theories
}

\author{
Jasna Milošević Đorđevića ${ }^{a b}$, Iris Žeželj ${ }^{\mathrm{c}}$, Živojin Đurićb \\ [a] Faculty of Media and Communications, Singidunum University, Belgrade, Serbia. [b] Institute for Political Studies, Belgrade, Serbia. [c] Faculty of Philosophy, \\ University of Belgrade, Belgrade, Serbia.
}

Journal of Social and Political Psychology, 2021, Vol. 9(1), 144-158, https://doi.org/10.5964/jspp.5609

Received: 2019-06-10 • Accepted: 2020-12-14 • Published (VoR): 2021-02-26

Handling Editor: Silvia Mari, University of Milano-Bicocca, Milan, Italy

Corresponding Author: Jasna Milošević Đorđević, Faculty of Media and Communications, Singidunum University, Serbia, Karadjorđeva 65, 11000 Belgrade, Serbia. E-mail: jasna.milosevic@fmk.edu.rs

Supplementary Materials: Materials [see Index of Supplementary Materials]

\begin{abstract}
Conspiracy mentality is a general tendency to attribute significant events to the actions of malevolent actors, without referencing to a specific event. In two independent representative surveys of adult Serbian citizens (N1 = 1194; N2 = 1258) we validated Serbian version of the conspiracy mentality questionnaire (CMQ), a reasonably content-free tool designed to capture global conspiratorial beliefs. We successfully validated the adapted CMQ and replicated findings on two national representative samples. In both studies the results demonstrated: good psychometric properties of the CMQ and its predictive capacity for endorsing the international Conspiracy Theories (CTs) (Study 1) and the locally specific CTs (Study 2) over and above the measures of perceptions of political climate (trust in institutions, corruption perception, feeling of insecurity - Study 1), and generalized political attitudes (right-wing authoritarianism, social dominance orientation, political cynicism - Study 2). The study presents a unique adaptation and implementation of the CMQ in the non-English speaking country with very active and widespread conspiracy beliefs and a long history of conflicts.
\end{abstract}

\section{Keywords}

conspiracy mentality, local-universal conspiracy theories, political attitudes, political climate

\section{Sažetak}

Zaverenički mentalitet predstavlja generalnu tendenciju ljudi da se značajni događaji pripisuju postupcima zlonamernih aktera, bez pominjanja određenih događaja. U dve nezavisne studije na reprezentativnim uzorcima punoletnih građana Srbije (N1 = 1194; N2 = 1258) verifikovali smo verziju upitnika o zavereničkom mentalitetu na srpskom jeziku, instrumenta koji je dizajniran da bez specifičnog sadržaja meri globalna zaverenička uverenja. Rezultati su uspešno potvrdili instrument i reprodukovali nalaze na dva nacionalna reprezentativna uzorka. Obe studije su pokazale: dobra psihometrijska svojstva instrumenta u odnosu na druge instrumente koji mere verovanje u međunarodne teorije zavere (Studija 1) i lokalno specifične teorije zavere (Studija 2); prediktivnu sposobnost koncepta u predviđanju percepcije političke klime (poverenje u institucije, percepcija korupcije, osećaj ne-sigurnosti Studija 1), i generalnih političkih stavova (desničarska autoritarnost, orijentacija na socijalnu dominaciju, politički cinizam - Studija 2). Studija predstavlja jedinstvenu adaptaciju i primenu instrumenta za merenje zavereničkog mentaliteta u zemlji van engleskog govornog područja sa vrlo aktivnim i raširenim zavereničkim uverenjima, kao i dugom istorijom etničkih sukoba.

\section{Ključne reči}

Zaverenički mentalitet, lokalno-univerzalne teorije zavere, politički stavovi, politička klima 
In an atmosphere of global uncertainty, in which misinformation spreads faster than ever via digital media, endorsing theories of conspiracy - an overarching "skeptical" narratives that contrasts the official ones - can help a person navigate the ever changing and often confusing world (Van Prooijen \& Jostmann, 2013; Wood \& Douglas, 2015). Conspiratorial tendencies are defined as a belief that important societal events, especially negative ones, are a result of hidden actions of certain secret powerful groups. Violent tensions and ethnic conflict tend to increase negative psychological repertoire, such as belief in conspiracy theories (CTs). Scholars argue that the need for cognitive closure and uncertainty threat foster conspiracy beliefs about events that lack clear official explanations (Marchlewska, Cichocka, \& Kossowska, 2018). Historical and conflict events in the Balkans clearly lack those kinds of explanations, leaving individuals without resources to cope with real or perceived threats. Additionally, other data suggested that higher anxiously attached individuals (Green \& Douglas, 2018) or collective narcissism with ethnic content (Marchlewska, Cichocka, Łozowski, Górska, \& Winiewski, 2019) would be more likely to hold conspiracy beliefs. Both are often present in the unstable societies, such as different Balkan countries.

Having in mind that conspiratorial view is a global phenomenon, parsing out the causes and consequences of the conspiracy beliefs in the region that suffered from war conflict in the recent history and ripe with the multiple CTs, presents an excellent experimental tool. Therefore, we think it is of great importance and implication for the field, to analyze conspiracy beliefs in Serbia. These beliefs are widespread on the Balkan, including Serbia, where many CTs are related to the past events in the region, often even in the distant past. To put this in a historical context, Balkan region has suffered from war conflicts and long occupations by foreign countries. During the middle ages it was occupied and ruled by Ottoman Empire for five centuries. After gaining independence from Ottomans in 1878, as a single ethnicity Kingdom of Serbia, at the end of the WWI was united with three other major Slavic groups, into the state in Southeast and Central Europe that existed until WWII. From 1918 to 1929 the state was officially called the Kingdom of Serbs, Croats and Slovenes, but the term "Yugoslavia" was its colloquial name. In both World Wars the human cost of the mentioned region was enormous, the exact number of war victims is still in dispute, but is generally agreed to have been at least one million. Following WWII, Socialist Federative Republic of Yugoslavia (SFRJ), formed as a federation of six republics, one of the Non-Aligned Movement founders and members under the rule of Josip Broz Tito (President-for-life), had been politically and economically stable in general. Nevertheless, this ambitious state project suffered from some weaknesses such as ethnical, religious and human rights issues. However, after Tito's death, the unify state failed to overcome number of challenges. As a result, Yugoslavia collapsed in a series of bloody conflicts, from secession of Slovenia and Croatia in 1991 and 1992 to the civil war in Bosnia and Croatia in mid-'90s and ended by NATO bombing of Serbia in 1999. The collapse of the SFRJ coincided with the global dissolution of the "Eastern bloc" by the end of the 1980s and in early 1990s (Milošević Đorđević et al., in press).

Western Balkans is still particularly prone to CTs. Many include conspiratorial actors, international, local groups or individuals such as "malevolent plot by multiple actors working together" (Swami, 2012), and thus, by implication, indirectly against the public. Therefore, when examining the conspiracy beliefs, it is important to include endorsement of the global CTs as well as local CTs. This has an added value because the Balkan countries belong to a global "Western" world but also have suffered in the civil war. Being on the European territory, the population of Serbia is also facing social overrepresentation of "fake news" accusations and other alternative explanations for dramatic recent global events. For example, the belief of conspiracies behind the global COVID-19 pandemic (e.g., "coronavirus was dangerous biological weapon designed by scientists in a military lab in Wuhan"), climate change (e.g., "HAARP system can control the weather" or "Airplane traces in the sky contain chemicals that pollute the environment and poison people"), or economic and political globalization ("NGOs like Georg Soros's Open Society Fund and masons are undermining the political systems”). Beside those mentioned, false claims concerning local political rivals and explanations of the past war conflicts still exists in the Balkans. For example, for the majority of the Serb population, the responsibility for the collapse of the state lies in the joint actions of the USA, Germany, Vatican, Slovenia, and Croatia (Milošević Đorđević et al., in press). On the other hand, the most prevalent Western interpretation of the civil war is that the SFRJ collapse was caused by Serbs holding all the power in the Yugoslav institutions and undermining other republics. For the Western audience, Serbia's secret agenda was forming a new entity of a so-called Greater Serbia (Kovačević, 2020; Volcic \& Erjavec, 2009). Some of these CTs are embedded in the official accounts of the Yugoslav conflicts. 
We examined population in this region outside of the English-speaking Western world, with a long history of war and violence, to examine the conspiracy mentality. Arguably, identifying processes that are lying behind conspiracy belief becomes a much more existential task in this setting. Thus, an extension of research to Serbian territory is very important, because being the target of a CT can become a lethal threat not only on the basis of the actions of some individual acting in the $\mathrm{CT}$, but as a matter of minority suppression. In addition, we tested the replicability of the results in two separate studies on high quality representative samples.

To capture individual differences in conspiratorial tendencies, psychologists have developed two different sets of measures: (a) endorsement of different real-world CTs, and (b) endorsement of a more generic 'conspiracy mentality', a general tendency to attribute significant events to the actions of malevolent actors, without referencing to a specific event (Swami et al., 2017). The former usually refers to a singular event (e.g. moon-landing is staged; the assassinations of popular figures happened differently than media presented it) or classes of events (e.g. HAARP system controls the weather; "chemtrails" are toxic to people and environment). Having in mind historical specifics of the region, we developed two different types of specific CTs that include global plots controlled by secret centers of power and specific CTs, mostly related to the breakup of Yugoslavia.

The need for a general measure of conspiracy belief was twofold: (a) when measuring endorsement of specific CTs, there is always noise coming from their content that affects their selective endorsement (e.g. hardly any are politically neutral), and (b) the events and actors that constitute specific CTs are always dependent on the context and moment in history. To enable important cross-cultural comparisons and significant relations with relevant correlates, a wide-ranging approach was called for. In the recent overview by Goreis and Voracek (2019), thirteen questionnaires have been used to measure conspiracy beliefs in the last decade, and two of most-used scales measured generic beliefs without specific conspiracies (GCBS; Brotherton, French, \& Pickering, 2013; and CMQ; Bruder et al., 2013). However, other scales with specific content about conspiracies also exist, like Conspiracy Theory Questionnaire (CTQ, Darwin, Neave, \& Holmes, 2011) and Generic Conspiracist Belief Scale (GCBS, Brotherton et al., 2013). Here, we used a short version of Conspiracy Mentality Questionnaire (CMQ, a 12-item and 5-item version) in both studies. The CMQ was conceived and validated by Bruder and colleagues (Bruder et al., 2013; Imhoff \& Bruder, 2014). Conspiracy mentality is typically described as a general political attitude, different from similar constructs, such as right-wing authoritarianism (RWA; Altemeyer, 1988) and social dominance orientation (SDO; Pratto, Sidanius, Stallworth, \& Malle, 1994). To prove it is a distinct ideological belief system, researchers demonstrated that it relates differently to prejudice than these two measures - whilst the conspiracy mentality predicted prejudice towards high power groups, SDO and RWA lead to more prejudice towards low power ones (Imhoff \& Bruder, 2014).

The CMQ is widely used and conceived as a measure that would guarantee more invariance in cross-cultural research. However, it has been adapted to a relatively modest number of languages (to our knowledge English, German, Turkish and French). In addition, its measurement characteristics have not been always proven robust (see, for example, Swami et al., 2017). Namely, one-factor solution fitted in some samples (German and English speaking), but proved inadequate in other samples (e.g. Turkish). Additionally, reported internal consistency also varied widely. This could partially be attributed to the lack of construct validity: whilst some statements clearly reflect conspiratorial ideation (e.g. I think that events which superficially seem to lack a connection are often the result of secret activities), others can be viewed as statements of fact, especially in a light of current findings regarding unauthorized gathering of personal data by institutions and corporations (e.g. I think that government agencies closely monitor all citizens).

Having all this in mind, drawing from two independent representative samples of adult Serbian citizens, we set out to explore:

a. The internal consistency and uniqueness of the $\mathrm{CMQ}$ instrument compared with similar constructs; we think it is of high relevance to further explore construct validity of CMQ and its predicting power to predict specific CTs, due to constantly evolving nature of CTs. In the area of CTs, specific theories (at least those with immediate political relevance) are so fluid, that a generic measure is called for. In some studies, strong claims have been made about comparative viability of different measures based on a not so strong empirical data (Swami et al., 2017). Therefore, it is critical that further research is being brought into the public domain, testing whether different scales stand up to 
scrutiny, especially on a high quality sampling from the underrepresented non-English speaking region, such as Balkans.

b. How generic conspiracist ideation (CMQ) relates to belief in concrete $\mathrm{CTs}$ - international ones adapted from Belief in Conspiracy Theory Inventory (Study 1) or the local CTs, typical for the Balkan region, designed specifically for the study (Study 2);

c. If the predictive power of CMQ for belief in concrete CTs goes over and above measures of perceptions of political climate - trust in institutions, corruption perception, feeling of insecurity (Study 1), and over and above the measures of generalized political attitudes - right-wing authoritarianism, social dominance orientation and political cynicism (Study 2).

We conducted both studies with a full sampling procedure (including random walk procedures, random selection of households and household members) resulting in two representative samples of the Serbian population. This procedure allows limiting self-selection bias and ensuring representation much more, than almost all other studies on conspiracy mentality in the literature using samples of participants recruited online or focused on targeted student population. For example, the recent meta-analysis by Goreis and Voracek (2019) states only two studies using representative samples (Hollander, 2018, in the US; Mancosu et al., 2017 in Italy). However, both of mentioned studies focus on specific CTs, while we included the generic belief in CTs and two types of specific CTs, local and global. Other authors found heterogeneity in designs and operationalization in the study of conspiracy beliefs, while asking for consensus. Our study is in line with this call. Therefore, this manuscript provides further evidence for the viability of one of the two most often-used questionnaires to assess conspiracy mentality. Additional strength is that issue is reported from two studies that are conceptual replications of one another.

We expect that the instrument will show good internal reliability and that measurement model will show it to be a distinct construct in comparison to other measures of political climate (Study 1) and other measures of generalized political attitudes (Study 2) even in the non-English speaking region with a strong conflict history (H1). We also hypothesized that it will predict both internationally (Study 1) and locally relevant (Study 2) specific CTs (H2). Finally, we expected it to provide a unique contribution to belief in concrete CTs, above the measures of political climate (Study 1) and climate coupled with the political attitudes (Study 2) (H3).

\section{Study 1}

\section{Method}

\section{Respondents and Sampling}

A total of 1194 adult citizens of Serbia were recruited in a stratified three-stage probability sampling procedure in November 2016 by the Institute of Political Studies, Belgrade. The sampling frame was based on the data from 2011 Census. The first stage sampling was done by polling station territory (212 sampling points). The second stage were households selected by random route technique starting from the randomly selected addresses (6 households by sampling points). The third were respondents randomly selected within households. The average length of the interview was $30 \mathrm{~min}$. Research procedures adhered to the APA ethical guidelines. Table 1 summarizes the demographic characteristics of the both samples. 
Table 1

Demographic Profile of the Sample in Study 1 and Study 2

\begin{tabular}{lcc}
\hline & \multicolumn{2}{c}{ Percent } \\
\cline { 2 - 3 } Sample structure & Study $\mathbf{1}$ & Study 2 \\
\hline Gender & 52 & 53 \\
$\quad$ Male & 48 & 47 \\
$\quad$ Female & & \\
\hline Education & 13 & 15 \\
$\quad$ Primary school and lower & 62 & 60 \\
$\quad$ Secondary school & 24 & 25 \\
$\quad$ University and higher & & \\
\hline Age & 15 & 15 \\
$\quad$ 18-25 & 40 & 40 \\
$26-45$ & 45 & 45 \\
$\quad 46+$ & & \\
\hline Ethnicity & 85 & 14 \\
$\quad$ Serb & 14 & 1 \\
Other & 1 & 1258 \\
$\quad$ Refused to declare & 1194 & \\
Total number of respondents & & \\
\hline
\end{tabular}

\section{Instruments}

We added full questionnaire in English and Serbian language into the Supplementary Materials.

Conspiracy mentality was assessed with a five-item version of CMQ (Bruder et al., 2013) with an 11-point scale, from 1 (completely false) to 11 (completely true) $(\alpha=.81$ ).

Questionnaire for specific CTs consisted of international CTs (e.g. Moon landing was staged; Vapor trails left by aircraft are actually chemicals that pollute the environment and are toxic to people; People are deceived about vaccine safety) anchored 1 (I do not agree at all) to 7 (I completely agree) $(\alpha=.88)$. The items were chosen based on several validated instruments, such as Belief in Conspiracy Theory Inventory (Swami et al., 2011), Vaccination Conspiracy Scale (Shapiro, Holding, Perez, Amsel, \& Rosberger, 2016), Conspiratorial narratives (Oliver \& Wood, 2014).

Respondents reported how much they (dis)trust nine public institutions (e.g. federal government, parliament, police, army, president, and judiciary), on a scale from 1 (I completely trust) to 4 (I do not trust at all) $(\alpha=.91$ ).

Respondents reported about corruption perception in the society in general on six items (Sampford, 2016) (e.g. Public employees use their positions for personal gain; Contracts are given to the companies that offer highest bribes to public officials) with a scale from 1 (never) to 7 (always) ( $\alpha=.93$ ).

Respondents assessed how secure they perceive the world in general, the region, and their personal surroundings using a scale from 1 (I don't feel secure at all) to 5 (I feel completely secure) $(\alpha=.69)$.

\section{Results}

To test the independence of constructs employed as predictors in Study 1 (Conspiracy mentality, Feeling of security, Trust in government institutions, Corruption perception), we ran a confirmatory factor analysis in AMOS (Version 18). Since we tested predictive power of CMQ for perceptions of political climate we ran only four factor model and did not include in the model the similar concept to $\mathrm{CMQ}$ (such as global CT). A proposed four-factor model fitted the data well, as the indices demonstrate: Chi-square $=1429.8$, Chi-square $/ d f=1429.8 / 201=7.11$, Comparative fit index $(\mathrm{CFI}=.92)$, Bentler-Bonett Normed Fit Index $(\mathrm{NFI}=.90)$, Root Mean Square Error Of Approximation (RMSEA) = .07. All the items loaded on the designated factors with loadings ranging from .66 to .83 for conspiracy mentality; from .62 to .82 for trust 
in institutions; from 0.85 to 0.90 for corruption perception; and from .66 to .89 for the feeling of security. This allowed us to treat the conspiracy mentality as an empirically different construct from the other three.

As the CMQ explores global conspiratorial tendencies, it should not be particularly sensitive to any preexisting knowledge, whilst endorsement of concrete CT depends on their familiarity. Therefore, all respondents assessed the truthfulness of the CMQ items, and only those who previously heard about a specific CT assessed its truthfulness. Due to this restriction, we did not impute missing data for these questions, but instead, we run the analysis on the subsamples of those familiar with specific CTs.

The average agreement with five statements from conspiracy mentality questionnaire was $M=7.88$, on an eleven-point scale. Most endorsed item was "Politicians usually do not tell us the true motives for their decisions" $(M=$ 8.60, $S D=2.80)$, and least endorsed was "Government agencies closely monitor all citizens $(M=6.67, S D=3.08)$ ". In exploratory factor analysis, all items loaded on one factor, explaining $57.98 \%$ variance.

The average agreement with eight statements from the specific CT scale was $M=4.86$ (out of seven). The agreement with the specific CTs varied from $M=4.40, S D=2.12$ for "The moon landing by the US astronaut was staged" to $M=$ $5.44, S D=1.72$ for "Big corporations are working towards systematically eradicating minority populations throughout the world". All descriptive measures are detailed in Table 2.

\section{Table 2}

CMQ and International CTs Scale Item Statistics, Study 1

\begin{tabular}{|c|c|c|c|}
\hline CMQ and international $\mathrm{CT}$ item & $M$ & $S D$ & $\begin{array}{c}\text { Factor } \\
\text { loadings }\end{array}$ \\
\hline \multicolumn{4}{|l|}{ Conspiracy Mentality Questionnaire $(\min 1 \max 11)$} \\
\hline Many important things happen in the world, which the public is never informed about. & 7.85 & 3.01 & .72 \\
\hline Politicians usually do not tell us the true motives for their decisions. & 8.60 & 2.80 & .78 \\
\hline Government agencies closely monitor all citizens. & 6.67 & 3.08 & .66 \\
\hline Events which superficially seem to lack a connection are often the result of secret activities. & 7.86 & 2.73 & .83 \\
\hline There are secret organizations that greatly influence political decisions. & 8.44 & 2.72 & .81 \\
\hline \multicolumn{4}{|l|}{ International CTs $(\min 1 \max 7)$} \\
\hline $\begin{array}{l}\text { Big corporations are working towards systematically eradicating minority populations throughout } \\
\text { the world. }\end{array}$ & 5.44 & 1.72 & .68 \\
\hline $\begin{array}{l}\text { NGOs like Georg Soros's Open Society Fund and similar organizations do nothing but spy and } \\
\text { undermine the political systems of the countries they operate in. }\end{array}$ & 5.12 & 1.81 & .76 \\
\hline Masons are a secret organization that governs the world behind the scene. & 5.11 & 1.81 & .70 \\
\hline HAARP system can control the weather. & 4.84 & 1.94 & .74 \\
\hline Airplane traces in the sky contain chemicals that pollute the environment and poison people. & 4.75 & 2.10 & 67 \\
\hline The 2001 attack on WTC in NY was organized by the US secret services. & 4.73 & 2.05 & .77 \\
\hline The gay lobby is behind most of important political decisions in the world. & 4.46 & 2.06 & .73 \\
\hline The moon landing by the US astronauts was staged. & 4.40 & 2.12 & .78 \\
\hline People are deceived about vaccine safety. & 4.40 & 2.10 & .64 \\
\hline
\end{tabular}

Note. $\mathrm{CMQ}=$ Conspiracy Mentality Questionnaire; $\mathrm{CT}$ = Conspiracy theory. 
As expected, conspiracy mentality and endorsement of specific CTs were highly correlated, $r(619)=.49, p<.001$. The conspiracy mentality also highly positively correlated with corruption perception, $r(929)=.42, p<.001$, and slightly positively with distrust in institutions, $r(880)=.08, p=.021$, whilst it was unrelated with the perception of security (Table 3).

Table 3

Correlation Matrix for All Measured Variables, Study 1

\begin{tabular}{lccccc}
\hline Measured variable & $\mathbf{1}$ & $\mathbf{2}$ & $\mathbf{3}$ & $\mathbf{4}$ & $\mathbf{5}$ \\
\hline Specific CTs (1) & - & $.49^{* * *}$ & $.20^{* * *}$ & $.19^{* * *}$ & -.05 \\
CMQ (2) & & - & $.42^{* * *}$ & $.08^{* *}$ & -.04 \\
Corruption perception (3) & & & - & $.28^{* * *}$ & -.05 \\
Distrust in institutions (4) & & & & - & $-.22^{* * *}$ \\
Perception of security (5) & & & & & - \\
\hline$M$ & 4.81 & 7.87 & 1.92 & 1.24 & 3.05 \\
$S D$ & 1.40 & 2.18 & 0.56 & 0.71 & 0.93 \\
\hline
\end{tabular}

${ }^{*} p<.05 .{ }^{* *} p<.01 .{ }^{* * *} p<.001$.

To test the predictive power of conspiracy mentality for endorsement of specific CTs over and above perceptions of political climate, we conducted a hierarchical regression in which we entered the feeling of security, distrust in institutions and perception of corruption in the first step, and CMQ in the second. Whilst the first set of predictors explained around $9 \%$ of variance, adding the second resulted with $28 \%$ of variance explained $\left(\Delta R^{2}=.19\right)$. Regression models are presented in Table 4.

Table 4

Standardized Beta Coefficients for Predictors in Two Models, Study 1

\begin{tabular}{lccc}
\hline Measured variable & $\boldsymbol{\beta}$ & $\mathbf{B}$ & $\boldsymbol{p}$ \\
\hline Model 1 & $R=.30 ; R^{2}=.10 ; \Delta R^{2}=.09 ; \Delta F=16.67 ; p(\Delta F)<.001$ & \\
Distrust in institutions & 0.24 & 5.43 & $<.001$ \\
Corruption perception & 0.24 & 5.46 & $<.001$ \\
Feeling of security & -0.08 & -1.92 & .06 \\
\hline Model 2 & $R=.53 ; R^{2}=.28 ; \Delta R^{2}=.19 ; \Delta F=138.19 ; \mathrm{p}(\Delta F)<.001$ & \\
Distrust in institutions & 0.19 & 4.83 & $<.001$ \\
Corruption perception & 0.02 & 0.38 & .70 \\
Feeling of security & -0.07 & -1.78 & .08 \\
CMQ & 0.49 & 11.76 & $<.001$ \\
\hline
\end{tabular}

Additionally, to analyze the CMQ predicative value for endorsement of specific international CTs one by one, we conducted a series of regression analyses (Table 5). The CMQ proved to be a significant predictor of all nine specific CTs, from "Big business" conspiracy, to "Vaccine safety" conspiracies. 
Table 5

Regression Analyses: CMQ Predictive Values of Specific International CTs, Study 1

\begin{tabular}{|c|c|c|c|c|}
\hline Specific international CTs item & $\boldsymbol{R}$ & $R^{2}$ & $\Delta F$ & $p(\Delta F)$ \\
\hline $\begin{array}{l}\text { Big corporations are working towards systematically eradicating minority populations } \\
\text { throughout the world. }\end{array}$ & .42 & .18 & 208.84 & $<.001$ \\
\hline $\begin{array}{l}\text { NGOs like Georg Soros's Open Society Fund and similar organizations do nothing but } \\
\text { spy and undermine the political systems of the countries they operate in. }\end{array}$ & .41 & .17 & 179.60 & $<.001$ \\
\hline Masons are a secret organization that governs the world behind the scene. & .32 & .11 & 106.47 & $<.001$ \\
\hline HAARP system can control the weather. & .28 & .08 & 71.32 & $<.001$ \\
\hline $\begin{array}{l}\text { Airplane traces in the sky contain chemicals that pollute the environment and poison } \\
\text { people. }\end{array}$ & .22 & .05 & 46.54 & $<.001$ \\
\hline The 2001 attack on WTC in NY was organized by the US secret services. & .32 & .10 & 106.44 & $<.001$ \\
\hline The gay lobby is behind most of important political decisions in the world. & .30 & .09 & 87.18 & $<.001$ \\
\hline The moon landing by the US astronauts was staged. & .34 & .12 & 115.50 & $<.001$ \\
\hline People are deceived about vaccine safety & .28 & .08 & 78.47 & $<.001$ \\
\hline
\end{tabular}

Note. $\mathrm{CMQ}=$ Conspiracy Mentality Questionnaire; $\mathrm{CT}$ = Conspiracy theory.

In order to explore further confirmation about the validity and predicting value of CMQ instrument in Serbia, we kept investigating those issues using similar methodology in Study 2. We tested CMQ as oppose to local CTs from the Balkan region, and its predictive value for general political attitudes (right-wing authoritarianism, social dominance orientation and political cynicism).

\section{Study 2}

\section{Method}

\section{Respondents and Sampling}

A total of 1258 adult citizens of Serbia were recruited in a stratified three-stage probability sampling procedure in May 2017. The sampling procedure was the same as previously described for Study 1. The sample's demographic breakdown is presented in Table 1. All research procedures adhered to the APA ethical guidelines.

\section{Instruments}

We used the same instruments as in Study 1 to assess conspiracy mentality $(\alpha=.83)$, distrust in institutions $(\alpha=.93)$, corruption perception $(\alpha=.93)$ and security $(\alpha=.76)$.

For this study, we used a set of six regionally widespread CTs, all related to the dissolution of former Yugoslavia. They included the actions of local and international politicians during and after the conflict (e.g. Presidents Milošević and Tuđman agreed in Karađorđevo how to divide Bosnia and Herzegovina; The crimes against the civilian population in action Flash and Storm were part of the systematic policy of ethnic cleansing devised beforehand by the Croatian authorities; World Bank, MMF and other international institutions economically and financially colonize Serbia for several decades). When choosing the specific CTs, we relied upon the ones validated on Croatian sample (Blanuša, 2013), 
as well as Serbian forums, blogs and social media groups formed around various CTs. Respondents expressed their endorsement on a scale from 1 I do not agree at all to 5 I completely agree $(\alpha=.71)$.

Right-wing authoritarianism was measured with a nine-item version of Altemeyer's RWA scale such as the most important virtue that a child should learn is obedience and respect for authority (Altemeyer, 1988, 1998) adapted for Serbian sample (as in Todosijević, 2013; Enyedi \& Todosijević, 2003) $(\alpha=.92)$.

Social dominance orientation scale comprised of eight items (Ho et al., 2015) adapted for Serbian (as in Jovanović et al., 2017; Žeželj \& Pratto, 2017), with typical statements such as "Some groups of people are simply inferior to other groups”, anchored with 1 (I completely disagree) to 5 (I completely agree) $(\alpha=.70)$.

Political cynicism was assessed by eight items derived from a widely-used scale (Dekker \& Meijerink, 2012; Schyns \& Nuus, 2007) adapted for Serbian (Pavlović, 2013), with statements like "Political parties are only interested in my vote and not my opinion”, anchored with 1 (I completely disagree) to 5 (I completely agree) $(\alpha=.94)$.

\section{Results}

To test if conspiracy mentality can be viewed as the empirically distinct construct in comparison to measures of generalized political attitudes, we ran a confirmatory factor analysis in AMOS (Version 18). In the Study 2 we tested predictive power of CMQ for general political attitudes and did not include in the model other similar concepts (such as regional CT). Again we ran four-factor model with only new additional variables of general political attitudes. A four-factor model fitted the data well: Chi-square $=1849.4$, Chi-square $/ d f=1849.4 / 368=5.02$, Comparative fit index (CFI $=.92)$, Bentler-Bonett Normed Fit Index $(\mathrm{NFI}=.90)$, Root Mean Square Error of Approximation (RMSEA) $=.06$. All items loaded on the designated factors with loadings ranging from .72 to .83 for conspiracy mentality; and from .69 to .81 for RWA; from .73 to .87 for political cynicism; and loadings from .68 to .82 for social dominance orientation.

In the Study 2, the average agreement with all items in CMQ was even higher than in the Study $1(M=8.14, S D=$ 2.74 out of eleven). The ranking of items mirrored the ranking from the first study exactly. Similarly, all items loaded on one factor that explained $60.72 \%$ variance.

The average endorsement of regional CTs was $M=3.47, S D=1.38$ on a five-point scale. Item loadings and averages are detailed in Table 6.

Table 6

CMQ and Local CTs Scale Item Statistics, Study 2

\begin{tabular}{|c|c|c|c|}
\hline $\mathrm{CMQ}$ and regional CTs scale item & $M$ & $S D$ & $\begin{array}{c}\text { Factor } \\
\text { loadings }\end{array}$ \\
\hline \multicolumn{4}{|l|}{ Conspiracy Mentality Questionnaire $(\min 1 \max 11)$} \\
\hline $\begin{array}{l}\text { I think that many very important things happen in the world, which the public is never informed } \\
\text { about. }\end{array}$ & 8.45 & 2.71 & .78 \\
\hline I think that politicians usually do not tell us the true motives for their decisions. & 8.88 & 2.56 & .78 \\
\hline I think that government agencies closely monitor all citizens. & 6.97 & 3.06 & .72 \\
\hline $\begin{array}{l}\text { I think that events which superficially seem to lack a connection are often the result of secret } \\
\text { activities. }\end{array}$ & 7.97 & 2.68 & .83 \\
\hline I think that there are secret organizations that greatly influence political decisions. & 8.44 & 2.68 & .79 \\
\hline
\end{tabular}




\begin{tabular}{|c|c|c|c|}
\hline CMQ and regional CTs scale item & $M$ & $S D$ & $\begin{array}{c}\text { Factor } \\
\text { loadings }\end{array}$ \\
\hline \multicolumn{4}{|l|}{ Regional CTs $(\min 1 \max 5)$} \\
\hline The European Union is a conspiracy of big business whose goal is the destruction of nation states. & 3.37 & 1.42 & .79 \\
\hline The Hague Tribunal was created with the main idea to only punish the Serbs. & 3.54 & 1.46 & .83 \\
\hline $\begin{array}{l}\text { World Bank, MMF and other international institutions economically and financially colonize Serbia } \\
\text { for several decades. }\end{array}$ & 3.68 & 1.32 & .82 \\
\hline $\begin{array}{l}\text { The crimes against the civilian population in actions Flash and Storm were part of the systematic } \\
\text { policy of ethnic cleansing devised beforehand by the Croatian authorities. }\end{array}$ & 4.06 & 1.22 & .70 \\
\hline $\begin{array}{l}\text { Serbian intellectuals and politicians in collaboration with the Jugoslav National Army (JNA) started } \\
\text { the wars in Croatia and Bosnia and Herzegovinato realize the idea of a Greater Serbia. }\end{array}$ & 2.81 & 1.51 & .87 \\
\hline Presidents Milosevic and Tudjman agreed in Karadjordjevo how to divide Bosnia and Herzegovina. & 3.39 & 1.36 & .77 \\
\hline
\end{tabular}

Even though we used a different set of concrete CTs compared to the first study (regional versus international), the average endorsement is still quite highly correlated with the CMQ, $r(1228)=.33, p<.001$. Similarly, out of political climate variables that were the same we used in the first study, CMQ was correlated the most with the perception of corruption, $r(1235)=.34, p<.001$, followed by distrust in institutions, $r(1218)=.19, p<.001$. When related measures of individual differences in general political attitudes were assessed, they were most highly correlated with political cynicism, $r(1232)=.28, p<.001$, significantly albeit weekly with RWA, $r(1227)=.07, p=.01$, and unrelated to the social dominance orientation. The full correlation matrix is presented in Table 7.

Table 7

Correlation Matrix for All Measured Variables, Study 2

\begin{tabular}{|c|c|c|c|c|c|c|c|c|}
\hline Measured variable & 1 & 2 & 3 & 4 & 5 & 6 & 7 & 8 \\
\hline Specific CT (1) & - & $.33^{* * *}$ & $.14^{* * *}$ & .03 & .02 & $.10^{* * *}$ & $.13^{* * *}$ & $.20^{* * *}$ \\
\hline CMQ (2) & & - & $.34^{* * *}$ & $.19^{* * *}$ & $.08^{* * *}$ & .05 & $.28^{* * *}$ & $.07^{* * *}$ \\
\hline Corruption perception (3) & & & - & $.33^{* * *}$ & $.12^{* * *}$ & $-.10^{* * *}$ & $.40^{* * *}$ & -.04 \\
\hline Distrust in institutions (4) & & & & - & $-.19^{* * *}$ & .01 & $-.26^{* * *}$ & $.25^{* * *}$ \\
\hline Feeling of security (5) & & & & & - & $.11^{\star * *}$ & -.02 & -.03 \\
\hline Social dominance (6) & & & & & & - & $-.09^{* * *}$ & $.08^{* * *}$ \\
\hline Political cynicism (7) & & & & & & & - & $-.17^{* * *}$ \\
\hline RWA (8) & & & & & & & & - \\
\hline$M$ & 3.23 & 7.90 & 5.73 & 1.33 & 3.13 & 2.55 & 4.03 & 1.68 \\
\hline$S D$ & 1.01 & 2.26 & 1.36 & 0.79 & 1.01 & 0.78 & 1.04 & 0.84 \\
\hline
\end{tabular}

${ }^{*} p<.05 .{ }^{* *} p<.01 .{ }^{* * *} p<.001$.

Following the same logic as in the first study, we conducted a hierarchical regression analysis, but this time with three steps. Measures of political climate (trust in institutions, perceived corruption, and feeling of security) explained 3\% of the variance in local CTs, adding a set of general political attitudes (RWA and SDO) resulted with the total of $11 \%$. Finally, adding CMQ significantly improved the predictive power, with additional $7.5 \%$ - in total $18.5 \%$ (Table 8). 
Table 8

Standardized Beta Coefficients for Predictors in Three Models, Study 2

\begin{tabular}{lccc}
\hline Measured variable included in & $\boldsymbol{\beta}$ & $\mathbf{B}$ & Sig \\
\hline Model 1 & $R=.17 ; R^{2}=.03 ; \Delta R^{2}=.03 ; \Delta F=10.67 ; p(\Delta F)<.001$ & \\
Trust in institutions & 0.11 & 3.57 & $<.001$ \\
Corruption perception & 0.16 & 5.22 & $<.001$ \\
Feeling of security & 0.03 & 0.96 & .34 \\
\hline Model 2 & $R=.33 ; R^{2}=.11 ; \Delta R^{2}=.08 ; \Delta F=33.17 ; p(\Delta F)=.00$ & .02 \\
Trust in institutions & 0.07 & 2.36 & $<.001$ \\
Corruption perception & 0.11 & 3.41 & .27 \\
Feeling of security & 0.03 & 1.11 & $<.001$ \\
RWA & 0.25 & 8.37 & $<.001$ \\
Political cynicism & 0.15 & 4.84 & $<.001$ \\
SDO & 0.09 & 3.06 & $<.001$ \\
\hline Model 3 & $R=.43 ; R^{2}=.13 ; \Delta R^{2}=.08 ; \Delta F=102.68 ; p(\Delta F)=.00$ & .25 \\
Trust in institutions & 0.10 & 3.19 & .13 \\
Corruption perception & 0.04 & 1.15 & $<.001$ \\
Feeling of security & 0.04 & 1.52 & $<.001$ \\
RWA & 0.21 & 7.40 & .02 \\
Political cynicism & 0.09 & 2.98 & $<.001$ \\
SDO & 0.06 & 2.32 & 10.13 \\
CMQ & 0.30 & & \\
\hline
\end{tabular}

Finally, to analyze the CMQ predictive power for endorsement of singular locally specific CTs, we conducted a set of regression analysis, similar to Study 1 (Table 9). The CMQ predicted endorsement of five out of six CTs - all except the one that blamed the ingroup (Serbs) and the Serbian institutions for initiating the Yugoslav civil wars, which was probably saturated with other constructs (such as attribution of guilt, ingroup bias, etc.) more than actual conspiratorial thinking.

\section{Table 9}

Regression Analysis: CMQ Predictive Values of Specific CTS

\begin{tabular}{|c|c|c|c|c|}
\hline Specific CTs & $\boldsymbol{R}$ & $R^{2}$ & $\Delta F$ & $p(\Delta F)$ \\
\hline The European Union is a conspiracy of big business whose goal is the destruction of nation states. & .34 & .12 & 153.74 & $<.001$ \\
\hline The Hague Tribunal was created with the main idea to only punish the Serbs. & .29 & .09 & 111.91 & $<.001$ \\
\hline $\begin{array}{l}\text { World Bank, MMF and other international institutions economically and financially colonize Serbia } \\
\text { for several decades. }\end{array}$ & .39 & .15 & 208.22 & $<.001$ \\
\hline $\begin{array}{l}\text { The crimes against the civilian population in actions Flash and Storm were part of the systematic } \\
\text { policy of ethnic cleansing devised beforehand by the Croatian authorities. }\end{array}$ & .22 & .05 & 60.26 & $<.001$ \\
\hline $\begin{array}{l}\text { Serbian intellectuals and politicians in collaboration with the Jugoslav National Army (JNA) started } \\
\text { the wars in Croatia and Bosnia and Herzegovina to realize the idea of a Greater Serbia. }\end{array}$ & .03 & .00 & 0.86 & .35 \\
\hline Presidents Milosevic and Tudjman agreed in Karadjordjevo how to divide Bosnia and Herzegovina. & .13 & .02 & 17.82 & $<.001$ \\
\hline
\end{tabular}

Note. $\mathrm{CMQ}=$ Conspiracy Mentality Questionnaire; $\mathrm{CT}$ = Conspiracy theory. 


\section{Discussion}

In two independent representative samples (total $N=2452$ ) the CMQ demonstrated excellent internal consistency and stable average scores by items over time. Exploratory factor analysis yielded one factor in both studies, indicating it is a unidimensional construct. Measurement models in both studies also supported the conspiracy mentality as a distinct construct, different from indicators of global political climate and generalized political attitudes.

Firstly, taken together, the two studies demonstrate that conspiracy mentality, as a global measure of tendency for conspiratorial thinking, predicts belief in the combined index of endorsement of international CTs (e.g. chemtrails, moon landing, 9/11) tested in Study 1 and the combined index of endorsement of more locally oriented CTs (e.g. IMF/World bank, Operation Storm), tested in Study 2. In separate regression analyses, it also predicted the endorsement of every single CT (apart from one) regardless of the fact that their content was very different. As the CMQ is a relatively content-free instrument, that captures susceptibility to doubt the official explanations of events and true intents of political actors, it might be viewed as a test of global worldview that may incorporate specific CTs. However, the relationship between specific CTs and conspiracy mentality was stronger in the first study which measured international conspiracies, than in the second which measured local ones. This could point out to some content-sensitivity.

Secondly, conspiracy mentality was also meaningfully related to the trustworthiness of political climate: higher conspiracy mentality was related to less trust in institutions and higher perception of corruption. Its relation with generalized political attitudes was also in line with the initial expectations: individuals who were more politically cynical and more authoritarian endorsed CM more. This is in line with previous studies demonstrating that authoritarian personalities tend to be more prone to CTs. This can be true for endorsing specific CTs (e.g. Abalakina-Paap, Stephan, Craig, \& Gregory, 1999; Grzesiak-Feldman \& Irzycka, 2009, but see also Swami, 2012), and for general conspiratorial attitudes (e.g. Bruder et al., 2013; for a comprehensive review see Grzesiak-Feldman, 2015). Political cynicism, insecurity, impaired trust in institutions and perception of corruption may be viewed as an indicator of anomie, and there is empirical base supporting the idea that CTs flourish in such circumstances, and are typical of distrustful and cynical individuals (Imhoff \& Bruder, 2014; Swami et al., 2011). There is a large body of research that investigated political climate fostering conspiracy mentality linking it to the low levels of trust, both interpersonal and institutional (Goertzel, 1994; Putnam, 2000). In a study that explored predictive power of anomie for endorsement of 20 specific CTs, anomie proved to be predictive over and above other measures of individual differences (Abalakina-Paap et al., 1999). In a similar study on a French-speaking Swiss sample, Wagner-Egger and Bangerter (2007) proved that anomie, distrust and belief in the malevolent world are powerful predictors of beliefs in CTs. More specifically, some studies focused on relation between political ideologies and believe in CTs. In the study on a US sample, left- and right-wing extremists participate in the CTs equally, but the patterns are different (Uscinski \& Parent, 2014). This was confirmed by another study on US and Netherlands samples (Van Prooijen, Krouwel, \& Pollet, 2015). There is evidence that the level of anomie and confidence in authority is higher in post-communist European societies in comparison to the Western European ones due to the rapid sociopolitical transition (Zhao \& Cao, 2010). Here, we explored the relations between these indicators, conspiratorial thinking and belief in specific CTs and have confirmed statistically significant correlation with distrust in institutions and corruption perception (Study 1 \& Study 2) and political cynicism and right-wing authoritarianism (Study 2). In our study, we did not register the relation of conspiracy mentality with social dominance orientation, which measures the value that people attribute to hierarchical relations among social groups (Sidanius \& Pratto, 1999), although some previous studies did find that higher social dominance orientation is related to more CTs endorsement (e.g. Grzesiak-Feldman, 2015). It might be due to the fact that these studies measured so-called "conspiracy stereotypes", beliefs about malevolent minority groups, which is more likely to be typical of people embracing the social hierarchy, whilst general conspiratorial attitudes regarding the global events can be weakly related or completely unrelated to social dominance orientation, as our results demonstrated.

Additionally, the predictive validity of the conspiracy mentality for specific CTs was consistent in the two studies. It predicted specific CTs over and above a set of measures that addressed the global climate of distrust and insecurity (Study 1), and even when measures of individual differences in political attitudes were included in the second step, it still added to the prediction (Study 2). These results clearly demonstrated that conspiracy mentality is a distinct 
psychological construct which cannot be equated with the other generalized political attitudes and that it can be a strong predictor of belief in CTs constructed around very diverse social events.

Lastly, we should point to several pluses of this study - the value of careful sampling methodology done in this study in a specific under-represented region. To our knowledge it is one of the very few studies that investigate CTs on the representative samples using face-to-face procedures, in a region with conflict history.

\section{Limitations}

We compared the predictive power of CM for both local and international CTs across studies. However, it would be even more informative to compare it in a single design. In addition, to have clearer insight about which instrument best captures the variance in global conspiratorial thinking, one would need to compare the CMQ to the other relevant measures. This leads us to another limitation of the study, that we have only one instrument for assessing CM. It would be valuable to use additional alternative instruments for assessing conspiracy mentality in our survey. Some of the statements from the CMQ that we used, lately have been a subject of academic criticism (being more factual statements, or likely to vary massively between different contexts). Results demonstrated divergent validity of one specific questionnaire in two high quality studies, besides acknowledging as a limitation the absence of alternative measurement for CMQ. Thus we believe this limitation does not constitute a substantive weakness of this report.

In the future studies, the Serbian version of the CMQ might be easily adapted for use in other countries in the region, the topic that warrants further studies. Lastly, future studies might include not only event-related, but also group-related CTs (so-called conspiracy stereotypes), and compare their relation to CM. This could be particularly relevant for the post-conflict Balkan region in which intergroup relations are fragile and full of mistrust.

\section{Conclusions}

There is a growing scholarly interest in the psychology of CTs (Butter \& Knight, 2020), and researchers have developed a broad range of different scales to measure individual differences in conspiracist ideation (Swami et al., 2017). Validation of $\mathrm{CMQ}$, as a main tool in these efforts, has been the subjected of this report: factorial and convergent validity, and internal consistency. The ongoing criticisms argues that CMQ only partially captures variance in the conspiratorial thinking, as some items can be seen as factual rather than conspiratorial, and its distribution is typically heavily skewed. However, our research asserted the CMQ to be structurally stable in two Serbian representative samples, as well as predictive of belief in concrete CTs, even the ones very specific to the context (the Balkans). These results indicate it can be a reliable tool for cross-cultural research. Our studies benefit from large, representative, culturally-homogeneous samples, with replication in two studies conducted in different period, confirming that scholars working on conspiracist ideation, may use CMQ for further investment.

Funding: This research was supported by the grant from the Serbian Ministry of Education, Science and Technological Development number 179009 . The authors have no other funding to report.

Competing Interests: The authors have declared that no competing interests exist.

Acknowledgments: This study is conducted within the framework COST Action CA 15101 "Comparative Analysis of Conspiracy Theories". We thank Ana Milošević for editing the manuscript. We also thank reviewers for their encouraging reviews that improved the paper a lot.

\section{Supplementary Materials}

The Supplementary Materials contain the questionnaire in English and Serbian language and Correlation tables of CMQ and specific belief in CT with socio-demographic (gender and education) (for access see Index of Supplementary Materials below). 


\section{Index of Supplementary Materials}

Milošević Đorđević, J., Žeželj, I., \& Đurić, Ž. (2021). Supplementary materials to "Beyond general political attitudes: Conspiracy mentality as a global belief system predicts endorsement of international and local conspiracy theories" [Questionnaire and correlation tables]. PsychOpen. https://doi.org/10.23668/psycharchives.4550

\section{References}

Abalakina-Paap, M., Stephan, W. G., Craig, T., \& Gregory, W. L. (1999). Beliefs in conspiracies. Political Psychology, $20,637-647$. https://doi.org/10.1111/0162-895X.00160

Altemeyer, B. (1988). Enemies of freedom: Understanding right-wing authoritarianism. San-Francisco, CA, USA: Jossey-Bass.

Altemeyer, B. (1998). The other "Authoritarian Personality." In M. P. Zanna (Ed.), Advances in experimental social psychology (Vol. 30, pp. 85-107). New York, NY, USA: Academic Press.

Blanuša, N. (2013). Internal memory divided: Conspiratorial thinking, ideological and historical cleavages in Croatia. Lessons for Europe. European Quarterly of Political Attitudes and Mentalities, 2, 16-33.

Brotherton, R., French, C. C., \& Pickering, A. D. (2013). Measuring belief in conspiracy theories: The Generic Conspiracist Beliefs scale. Frontiers in Psychology, 4, Article 279. https://doi.org/10.3389/fpsyg.2013.00279

Bruder, M., Haffke, P., Neave, N., Nouripanah, N., \& Imhoff, R. (2013). Measuring individual differences in generic beliefs in conspiracy theories across cultures: Conspiracy Mentality Questionnaire. Frontiers in Psychology, 4, Article 225. https://doi.org/10.3389/fpsyg.2013.00225

Butter, M., \& Knight, P. (Eds.). (2020). Routledge handbook of conspiracy theories. New York, NY, USA: Routledge.

Darwin, H., Neave, N., \& Holmes, J. (2011). Belief in conspiracy theories: The role of paranormal belief, paranoid ideation and schizotypy. Personality and Individual Differences, 50, 1289-1293. https://doi.org/10.1016/j.paid.2011.02.027

Dekker, H., \& Meijerink, E. (2012). Political cynicism: Conceptualization, operationalization, and explanation. Politics, Culture and Socialization, 3, 33-48.

Enyedi, Z., \& Todosijević, B. (2003). Organization of mass political attitudes in Hungary. Polish Psychological Bulletin, 34, 15-26.

Goertzel, T. (1994). Belief in conspiracy theories. Political Psychology, 15, 731-742. https://doi.org/10.2307/3791630

Goreis, A., \& Voracek, M. (2019). A systematic review and meta-analysis of psychological research on conspiracy beliefs: Field characteristics, measurement instruments, and associations with personality traits. Frontiers in Psychology, 10, Article 205. https://doi.org/10.3389/fpsyg.2019.00205

Green, R., \& Douglas, K. M. (2018). Anxious attachment and belief in conspiracy theories. Personality and Individual Differences, 125, 30-37. https://doi.org/10.1016/j.paid.2017.12.023

Grzesiak-Feldman, M. (2015). Are the high authoritarians more prone to adopt conspiracy theories? The role of right-wing authoritarianism in conspiratorial thinking. In M. Bilewicz, A. Cichocka, \& W. Soral (Eds.), The psychology of conspiracy (pp. 99-117). London, United Kingdom: Routledge.

Grzesiak-Feldman, M., \& Irzycka, M. (2009). Right-wing authoritarianism and conspiracy thinking in a Polish sample. Psychological Reports, 105, 389-393. https://doi.org/10.2466/PR0.105.2.389-393

Ho, A. K., Sidanius, J., Kteily, N., Sheehy-Skeffington, J., Pratto, F., Henkel, K. E., . . Stewart, A. L. (2015). The nature of social dominance orientation: Theorizing and measuring preferences for intergroup inequality using the new $\mathrm{SDO}_{7} \mathrm{scale}$. fournal of Personality and Social Psychology, 109, 1003-1028. https://doi.org/10.1037/pspi0000033

Hollander, B. A. (2018). Partisanship, individual differences, and news media exposure as predictors of conspiracy beliefs. Journalism \& Mass Communication Quarterly, 95, 691-713. https://doi.org/10.1177/1077699017728919

Imhoff, R., \& Bruder, M. (2014). Speaking (un-)truth to power: Conspiracy mentality as a generalised political attitude. European Journal of Personality, 28, 25-43. https://doi.org/10.1002/per.1930

Jovanović, O., Vladisavljević, M., Branković, M., \& Žeželj, I. (2017). Methods section: Quantitative and qualitative examination of social identities and their mutual relations. In F. Pratto, I. Žeželj, V. Turjačanin, E. Maloku, \& M. Branković, M. (Eds.), Shaping social identities after violent conflict (pp. 53-67). London, United Kingdom: Palgrave Macmillan.

Kovačević, D. (2020). Visions of Greater Serbia: Local dynamics and the Prijedor genocide. Genocide Studies and Prevention, 14(1), 105-123. https://doi.org/10.5038/1911-9933.14.1.1686 
Mancosu, M., Vassallo, S., \& Vezzoni, C. (2017). Believing in conspiracy theories: Evidence from an exploratory analysis of Italian survey data. South European Society and Politics, 22, 327-344. https://doi.org/10.1080/13608746.2017.1359894

Marchlewska, M., Cichocka, A., \& Kossowska, M. (2018). Addicted to answers: Need for cognitive closure and the endorsement of conspiracy beliefs. European fournal of Social Psychology, 48(2), 109-117. https://doi.org/10.1002/ejsp.2308

Marchlewska, M., Cichocka, A., Łozowski, F., Górska, P., \& Winiewski, M. (2019). In search of an imaginary enemy: Catholic collective narcissism and the endorsement of gender conspiracy beliefs. The fournal of Social Psychology, 159(6), 766-779.

https://doi.org/10.1080/00224545.2019.1586637

Milošević Đorđević, J., Žeželj, I., Turjačanin, V., Lukić, P., Gjoneska, B., \& Krouwel, A. (in press). Conspiracy theories about the conflict: Blaming the enemy or finding a joint culprit. In N. Blanuša (Ed.), Conspiracies in and about the Balkan. Routledge.

Oliver, J. E., \& Wood, T. J. (2014). Conspiracy theories and the paranoid style(s) of mass opinion. American fournal of Political Science, 58, 952-966. https://doi.org/10.1111/ajps.12084

Pavlović, Z. (2013). Prediktori izborne apstinencije mladih u Srbiji [Predictors of youth electoral absenteeism in Serbia]. Primenjena Psihologija, 6, 5-21. https://doi.org/10.19090/pp.2013.1.5-21

Pratto, F., Sidanius, J., Stallworth, L. M., \& Malle, B. F. (1994). Social dominance orientation: A personality variable predicting social and political attitudes. Fournal of Personality and Social Psychology, 67, 741-763. https://doi.org/10.1037/0022-3514.67.4.741

Putnam, R. D. (2000). Bowling alone: The collapse and revival of American community. New York, NY, USA: Simon and Schuster. Sampford, C. (2016). Measuring corruption. Abingdon, United Kingdom: Routledge.

Schyns, P., \& Nuus, M. (2007). Political cynicism and social cohesion in Europe and the United States. In F. Adam (Ed.), Social capital and governance: Old and new members of the EU in comparison (pp. 91-122). Berlin, Germany: LIT Verlag.

Shapiro, G. K., Holding, A., Perez, S., Amsel, R., \& Rosberger, Z. (2016). Validation of the vaccine conspiracy beliefs scale. Papillomavirus Research, 2, 167-172. https://doi.org/10.1016/j.pvr.2016.09.001

Sidanius, J., \& Pratto, F. (1999). Social dominance: An intergroup theory of social oppression and hierarchy. Cambridge, United Kingdom: Cambridge University Press.

Swami, V. (2012). Social psychological origins of conspiracy theories: The case of the Jewish conspiracy theory in Malaysia. Frontiers in Psychology, 3, Article 280. https://doi.org/10.3389/fpsyg.2012.00280

Swami, V., Barron, D., Weis, L., Voracek, M., Stieger, S., \& Furnham, A. (2017). An examination of the factorial and convergent validity of four measures of conspiracist ideation, with recommendations for researchers. PLoS One, 12, Article e0172617. https://doi.org/10.1371/journal.pone.0172617

Swami, V., Coles, R., Stieger, S., Pietschnig, J., Furnham, A., Rehim, S., \& Voracek, M. (2011). Conspiracist ideation in Britain and Austria: Evidence of a monological belief system and associations between individual psychological differences and real-world and fictitious conspiracy theories. British fournal of Psychology, 102, 443-463. https://doi.org/10.1111/j.2044-8295.2010.02004.x

Todosijević, B. (2013). Social, psychological and ideological roots of nationalist attitudes in Serbia. Psihologija, 46, $279-297$. https://doi.org/10.2298/PSI130411005T

Uscinski, J. E., \& Parent, J. M. (2014). American conspiracy theories. Oxford, United Kingdom: Oxford University Press.

Van Prooijen, J.-W., \& Jostmann, N. B. (2013). Belief in conspiracy theories: The influence of uncertainty and perceived morality. European Journal of Social Psychology, 43(1), 109-115. https://doi.org/10.1002/ejsp.1922

Van Prooijen, J. W., Krouwel, A. P. M., \& Pollet, T. V. (2015). Political extremism predicts belief in conspiracy theories. Social Psychological and Personality Science, 6(5), 570-578. https://doi.org/10.1177/1948550614567356

Volcic, Z., \& Erjavec, K. (2009). Nostalgia for Greater Serbia: Media coverage of Radovan Karadžic's arrest. fournal of Global Mass Communication, 11(1-2), 24-46.

Wagner-Egger, P., \& Bangerter, A. (2007). La vérite est ailleurs: corrélats de l'adhésion aux théories du complot. Revue Internationale de Psychologie Sociale, 20, 31-61.

Wood, M. J., \& Douglas, K. M. (2015). Online communication as a window to conspiracist worldviews. Frontiers in Psychology, 6, Article 836. https://doi.org/10.3389/fpsyg.2015.00836

Žeželj, I., \& Pratto, F. (2017). What identities in the present may mean for the future of the Western Balkans. In F. Pratto, I. Žeželj, V. Turjačanin, E. Maloku, \& M. Branković (Eds.), Shaping social identities after violent conflict (pp. 159-188). London, United Kingdom: Palgrave Macmillan.

Zhao, R., \& Cao, L. (2010). Social change and anomie: A cross-national study. Social Forces, 88, 1209-1229.

https://doi.org/10.1353/sof.0.0312 